\title{
Teratogenic Effect of Usnic Acid from Cladonia substellata Vainio during Organogenesis
}

\author{
C. R. Silva, ${ }^{1}$ K. S. N. Marinho, ${ }^{2}$ T. D. S. Silva, ${ }^{1}$ D. K. S. Ferreira, ${ }^{3}$ \\ G. M. Aguiar, ${ }^{3}$ M. C. B. Martins, ${ }^{1}$ K. R. P. Santos, ${ }^{3}$ F. C. A. Aguiar Júnior, ${ }^{3}$ \\ N. P. S. Santos, ${ }^{3}$ E. C. Pereira, ${ }^{4}$ and N. H. Silva ${ }^{1}$ \\ ${ }^{1}$ Laboratory of Chemistry of Natural Products, Department of Biochemistry, UFPE, Recife, PE, Brazil \\ ${ }^{2}$ Department of Morphology and Animal Physiology, UFRPE, Recife, PE, Brazil \\ ${ }^{3}$ Laboratory Biotechnology and Pharmaceuticals, Academic Center Academic of Vitória, UFPE, Recife, PE, Brazil \\ ${ }^{4}$ Department of Geographical Sciences, UFPE, Recife, PE, Brazil
}

Correspondence should be addressed to E. C. Pereira; verticillaris@gmail.com

Received 30 September 2016; Revised 6 January 2017; Accepted 18 January 2017; Published 27 February 2017

Academic Editor: Paul M. Tulkens

Copyright (C) 2017 C. R. Silva et al. This is an open access article distributed under the Creative Commons Attribution License, which permits unrestricted use, distribution, and reproduction in any medium, provided the original work is properly cited.

\begin{abstract}
Studies about toxicological potential of usnic acid are limited. This way, the vast majority of data available in the literature are related only to biological activities. This is the first study that aimed to evaluate the oral toxicity of usnic acid during the period of organogenesis. Females rats were distributed in the control groups, treated I and II, at doses of $15 \mathrm{and} 25 \mathrm{mg} / \mathrm{kg}$, administered by gavage during the $6^{\circ}$ to $15^{\circ}$ days of pregnancy. After 20 days the fetuses were removed and analyzed. A reduction in weight gain during pregnancy, increased resorption, reduction in the number of viable fetuses, and their body weight were observed. Morphological changes in the litter were visualized as exposure of the eye and atrophy of the limbs at the dose of $25 \mathrm{mg} / \mathrm{kg}$. Histological analysis of the liver of the fetus showed reduction in the number of megakaryocytes between experimental groups and increase in the number of hepatocytes in a dose of $25 \mathrm{mg} / \mathrm{kg}$. The experimental model used in this study reveals teratogenic effect of usnic acid in the period of organogenesis. Since this achievement, the importance of evaluating the toxic effects of natural substances is imperative, in order to elucidate the care in their indication as drug.
\end{abstract}

\section{Introduction}

Usnic acid [2,6-diacetyl-7,9-dihydroxy-1,3-dimethyl-8-9b $(2 \mathrm{H}, 9 \alpha / \beta \mathrm{H})$-dibenzo-furandione; $\mathrm{C}_{18} \mathrm{H}_{16} \mathrm{O}_{7}$ ] is a compound of natural origin resulting from lichen secondary metabolism. It is considered one of the most important biologically active metabolites with important pharmacological properties: antitumor, antibiotic, antiviral, antioxidant, tuberculostatic, anti-inflammatory, and molluscicide [1-10].

Despite the diverse pharmacological activities attributed to this compound, its use has shown damage to the main organ that acts in the detoxification of endo- and xenobiotics, the liver [11]. It was reported that usnic acid is one of the active ingredients of the supplement Lipokinetix ${ }^{\circledR}$, causing hepatocellular damage [12]. Data claim that these people who used this product had acute liver failure [13]. Already in vitro studies, isolated rat hepatocytes treated with different concentrations of usnic acid showed almost $100 \%$ of necrosis [14-16].

The mechanism of action of usnic acid is not fully elucidated. Studies mention this ability of decoupling of the chain of electron transport, affecting mitochondrial function and cellular respiration, effect similar to what happens to carbon tetrachloride $[12,14,17,18]$.

To evaluate the toxicity of naturally occurring substances, such as usnic acid, preclinical trials in order to evaluate the potential of the substance to cause adverse effects on exposed organisms are included, in particular the effects of exposure during pregnancy which is one of the basic requirements for the use of bioactive molecules $[19,20]$.

Experimental studies using animal models, traditionally, provide the basis for screening teratogenic potential of 


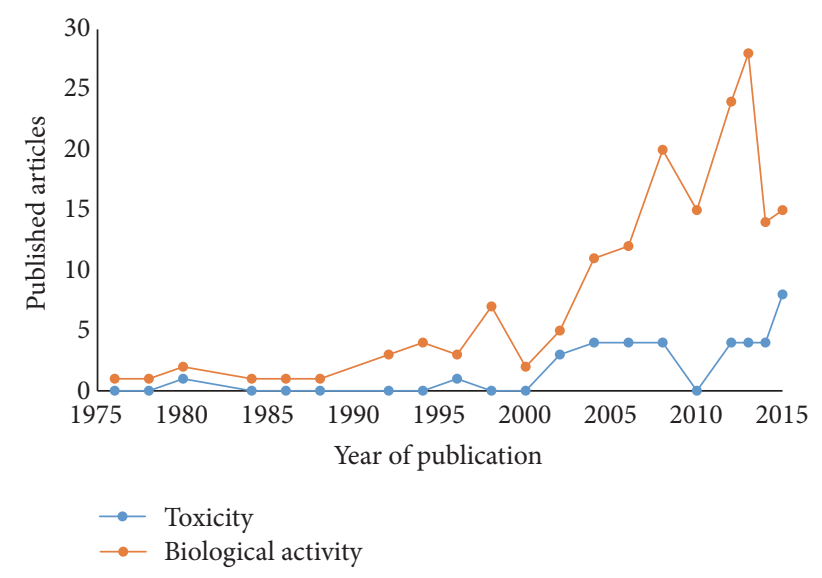

FIGURE 1: Scientific research on biological activity and toxicity of usnic acid. Source: Scopus.

substances to the verification of a particular agent to be considered toxic. These investigations have the key role in the elucidation of the principles and mechanisms involved in teratogenesis, which may be related to drug exposure conditions, stage of development of the embryos, and pathogenic mechanism of each agent [21].

In recent years there has been a breakthrough in the number of scientific researches to demonstrate the effectiveness of the various biological activities attributed to usnic acid (Figure 1).

However, studies about its toxicological potential are limited, so that the vast majority of data available in the literature are related only to the biological activities of compound [22-26].

Therefore, this is the first study that aimed to evaluate the oral toxicity of purified usnic acid from Cladonia substellata on the reproductive development of female rats during the period of organogenesis.

\section{Material and Methods}

2.1. Lichens Samples. Samples of Cladonia substellata Vainio were collected on sandy soils of "tabuleiro," savannah like vegetation, in Atlantic rainforest domain, along of Federal highway (BR 101), in the municipality of Mamanguape, Paraíba State, Northeast Brazil, coordinates $06^{\circ} 42^{\prime} 42,4^{\prime \prime} \mathrm{S}$ and $35^{\circ} 07^{\prime} 07,0^{\prime \prime}$ WGr.

The usnic acid, the main substance of the species, was extracted using the eluotropic series of solvents, diethyl ether, chloroform, and acetone [27]. Sequentially, it was isolated and purified in silica gel column from ether extract and characterized as preestablished methodology in the Natural Products Laboratory of the Department of Biochemistry, through analyses of HPLC, ${ }^{1} \mathrm{HNMR}$, and melting point [10]. Quantitation of usnic acid was carried out through HPLC, by injecting different amounts of purified usnic acid, and calculated by direct calibration. In addition, optical rotation of usnic acid was determined in a Jasco P2000 polarimeter in Analytical Centre of Fundamental Chemistry Department of Federal University of Pernambuco.
2.2. Experimental Animals. Wistar rats $(n=18)$ provided by the biotherium of the Department of Nutrition at the Federal University of Pernambuco, weighing about $300 \mathrm{~g}$ with 60 days of life, were used. The animals were kept in cages lined with air-conditioned environment in photoperiod (12 h light/12 h dark) at a controlled temperature of $25 \pm$ $2^{\circ} \mathrm{C}$ with exhaust air and free food access ad libitum water. The experimental protocols were approved by the Ethics Committee of the Federal University of Pernambuco (process number 23076.029828/2013-94).

2.3. Experimental Procedure. Initially, females were submitted to the study of the estrous cycle in order to determine the fertile period. The analysis was carried out by vaginal swab technique for obtaining slides containing vaginal epithelial cells which were stained by hematoxylin-Shorr. Subsequently, using an Olympus microscope (BH-2, Japan) was identified the period of ovulation of the female, called estrus in which the females were matched with male and the mating was confirmed by the presence of "plug" (whitish mass spermatozoa in the vaginal opening) or the presence of sperm in the vaginal smear. The first $24 \mathrm{~h}$ after confirmation of mating were considered day zero (D0) of gestation. Females were randomly distributed in the control groups $(n=6)$ treated I $(n=6)$ and treated II $(n=6)$. The control group received $1 \mathrm{~mL}$ of physiologic solution, while the treated groups I and II received the purified usnic acid in doses of $15 \mathrm{mg} / \mathrm{kg}$ and $25 \mathrm{mg} / \mathrm{kg}$ body weight, respectively. Doses were based on $50 \%$ of $\mathrm{LD}_{50}$ (lethal dose that kills $50 \%$ of the animals) determined to rats [28], and $25 \mathrm{mg} / \mathrm{kg}$, as recommended by Merck ${ }^{\circledR}$ index [29]. The doses of purified usnic acid were dissolved in $10 \mathrm{~mL}$ of PBS buffer Merck, and the product was administered orally (gavage), in daily doses, from 6th up to 15th day of pregnancy. During administration females were weighed to assess body mass gain at $0^{\circ}, 6^{\circ}, 10^{\circ}, 14^{\circ}$, and 20 days of gestation. After this period, the mice were euthanized by overdose of the anesthesia with Urethane $(1.25 \mathrm{~mL} / \mathrm{kg})$. Uteri were dissected, and after opening them, fetuses were removed and examined in the craniocaudal direction, to evaluate the presence of external malformations. Then, fetuses and their placentas were weighed.

The deployment sites were identified by iodine solution (Lugol 2\%). In free wombs of their content the deployment sites were visualized by contrast to the uterine tissue. Deployments appeared as bright spots that were located and accounted for. The number of resorptions was the result of the number of implantations sites minus the number of fetuses.

\subsection{Histomorphometric Analysis. For hepatotoxicity regis-} tration after euthanasia the livers of pregnant rats and fetuses were dissected and weighed and then subjected to histopathological analysis. The collected material was kept in buffered formalin solution (10\%) for $24 \mathrm{~h}$ and then processed for routine histological technique. The blocks were cut into $4 \mathrm{~mm}$ thick, by Manson trichrome stained, and analyzed by light microscopy (Olympus BH-2, Japan).

For histomorphometric analysis slides were photographed under fixed focus and clarity of field through Motic ${ }^{\circledR}$ 


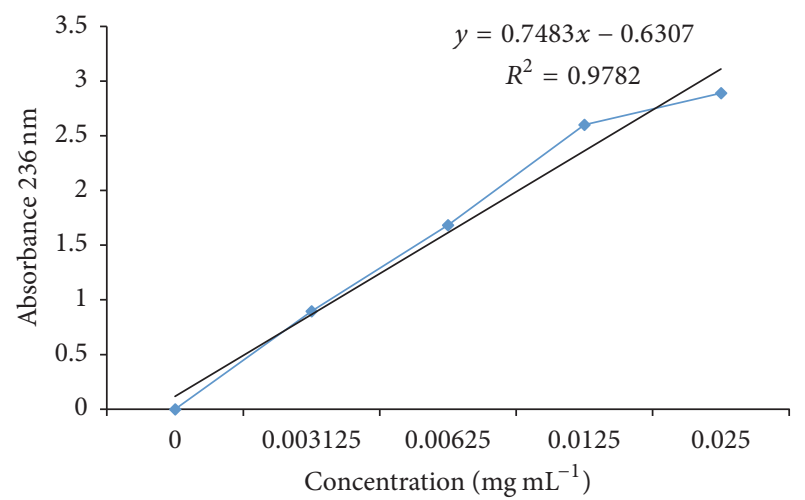

Figure 2: Calibration line of purified usnic acid from Cladonia substellata.

Images Plus 2.0 software with a digital camera attached to an optical microscope (Olympus BH-2, Japan) and connected to the computer. We obtained 30 photomicrographs per slide at full 400x magnification.

The photomicrographs were submitted to appropriate measurements using ImageJ software version 1:44 (Research Services Branch, U.S. National Institutes of Health, Bethesda, MD, USA). For the fetus, the following measurements were considered: number of hepatocytes $(\mathrm{NH})$ and number of megakaryocytes (NM), and for pregnant rats: number of hepatocytes (NH) and number of Kupffer cells (NCK).

2.5. Statistical Analysis. Data were expressed as mean \pm standard deviation (SD). Statistical significance was determined by one-way ANOVA followed by Tukey's test $P<0.05$ significant analysis. All analyzes were performed using Prism software (GraphPad Software, Inc., San Diego, CA, version $5.01)$.

\section{Results}

3.1. Chemical Analyses of Usnic Acid. Data of extraction, purification, and spectroscopic analyses of usnic acid used in this study were previously described [10]. The optical rotation was $\alpha_{25}^{D}:+478.2200$ (c 1.0 acetone). This way, the usnic acid used in our study is dextrorotary.

The thallus of C. substellata presented $95 \%$ of usnic acid, by direct calibration (Figure 2), and HPLC analyses showed $95 \%$ of purity.

3.2. Reproductive Variables Attributed to Pregnant Rats. During oral administration of purified usnic acid at $15 \mathrm{mg} / \mathrm{kg}$ and $25 \mathrm{mg} / \mathrm{kg}$, no death was registered during treatment. The pregnant rats in the experimental groups showed a significant reduction in body weight gain at 10,14 , and 20 days of gestation (Table 1). With respect to the total number of fetal resorptions, an increase in the group exposed to the dose of $25 \mathrm{mg} / \mathrm{kg}$, the presence small placentas, and further reduction in the number of fetuses were observed (Figure 3). The group exposed at $15 \mathrm{mg} / \mathrm{kg}$ remained close to the control group (Table 1).
TABLE 1: Reproductive variables attributed to pregnant rats.

\begin{tabular}{|c|c|c|c|}
\hline & \multicolumn{3}{|c|}{ Groups } \\
\hline & $\begin{array}{c}\text { G1 } \\
\text { (Control) }\end{array}$ & $\begin{array}{c}\mathrm{G} 2 \\
(15 \mathrm{mg} / \mathrm{kg})\end{array}$ & $\begin{array}{c}\mathrm{G} 3 \\
(25 \mathrm{mg} / \mathrm{kg})\end{array}$ \\
\hline \multicolumn{4}{|c|}{$\begin{array}{l}\text { Mean body weight } \\
\text { (g) }\end{array}$} \\
\hline Day 0 & $208 \pm 4.3$ & $209 \pm 5.6$ & $208 \pm 5.2$ \\
\hline Day 6 & $227 \pm 1.4$ & $227 \pm 3.1$ & $226 \pm 5.8$ \\
\hline Day 10 & $255 \pm 3.4$ & $236 \pm 3.8^{*}$ & $224 \pm 5.8^{* * *}$ \\
\hline Day 14 & $276 \pm 2.3$ & $250 \pm 2.8^{* * *}$ & $229 \pm 6.9^{* * *}$ \\
\hline Day 20 & $299 \pm 2.5$ & $279 \pm 3.6^{* * *}$ & $247 \pm 6.6^{* * *}$ \\
\hline $\begin{array}{l}\text { Number of } \\
\text { implantations }\end{array}$ & $12 \pm 0.5$ & $10 \pm 1.0^{*}$ & $8 \pm 1.4^{* * *}$ \\
\hline $\begin{array}{l}\text { Number of } \\
\text { resorptions }\end{array}$ & $1.1 \pm 0.4$ & $3.5 \pm 0.5^{*}$ & $5.0 \pm 1.0^{* * *}$ \\
\hline
\end{tabular}

Data are expressed as mean \pm standard deviation. ANOVA-Tukey. ${ }^{*} P<0.05$, ${ }^{* * *} P<0.001$ compared to the control group.

TABLE 2: Parameters of prole.

\begin{tabular}{lccc}
\hline & \multicolumn{3}{c}{ Groups } \\
& $\begin{array}{c}\mathrm{G} 1 \\
\text { (Control) }\end{array}$ & $\begin{array}{c}\mathrm{G} 2 \\
(15 \mathrm{mg} / \mathrm{kg})\end{array}$ & $\begin{array}{c}\mathrm{G} 3 \\
(25 \mathrm{mg} / \mathrm{kg})\end{array}$ \\
\hline $\begin{array}{l}\text { Mean body weight } \\
\text { g) }\end{array}$ & $5.7 \pm 0.3$ & $4.6 \pm 0.1^{*}$ & $3.5 \pm 0.1^{* * *}$ \\
Liver weight & $0.5 \pm 0.02$ & $0.3 \pm 0.02^{*}$ & $0.2 \pm 0.05^{* * *}$ \\
\hline
\end{tabular}

Data are expressed as mean \pm standard deviation. ANOVA-Tukey. ${ }^{*} P<0.05$, ${ }^{* * *} P<0.001$ compared to the control group.

3.3. Assigned Parameters to Prole. The treatment with usnic acid changed the parameters assigned to the offspring (average body weight, average weight of the livers, and external malformations). The average weight of fetuses and their placenta showed decrease by approximately $20 \%$ at $15 \mathrm{mg} / \mathrm{kg}$, while at $25 \mathrm{mg} / \mathrm{kg}$ a reduction of about 39\% was observed (Table 2 ). At $15 \mathrm{mg} / \mathrm{kg}$ a $32 \%$ reduction in the weight of fetal livers was observed. By the other hand, a relevant reduction of about $60 \%$ was observed in animals treated at $25 \mathrm{mg} / \mathrm{kg}$ (Table 2).

Concerning the external morphology, the fetuses treated at $25 \mathrm{mg} / \mathrm{kg}$ presented with abnormal patterns with disruption in their development (Figure 4), protrusion of the eyeball (Figure 5(a)), substantial mass proliferation in the region top of the face and neck (Figure 5(b)), and atrophy of the upper and lower limbs (Figure 5(c)). At $15 \mathrm{mg} / \mathrm{kg}$ none of those changes were displayed.

In the microanatomic examination of the liver of experimental groups, liver lobes consisting of cords of hepatic cells anastomosed to capillary sinusoids which were covered by endothelial cells and Kupffer cells were exhibited. A limit clear between the hepatic lobules with typical organization structures of port spaces was observed. It was not possible to visualize the space of Disse and Ito cells, indicating that there was no damage to the liver structure.

The liver of fetuses from experimental groups showed anastomosing cords of hepatic cells to capillary sinusoids. 


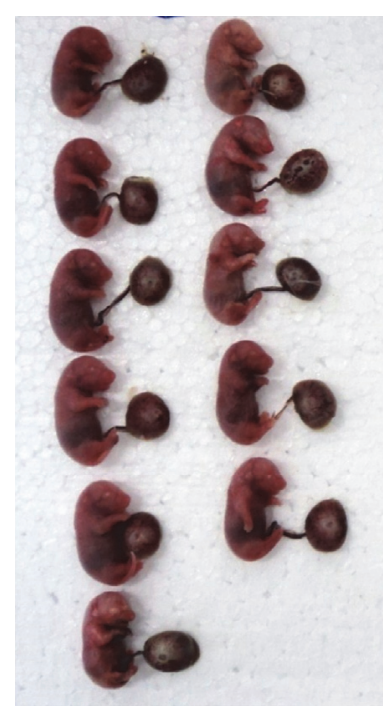

(a)

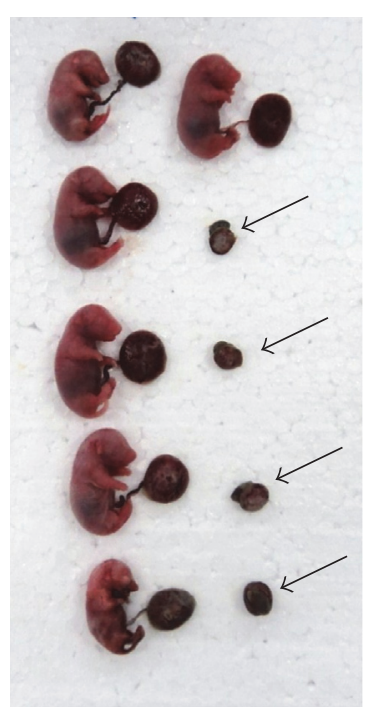

(b)

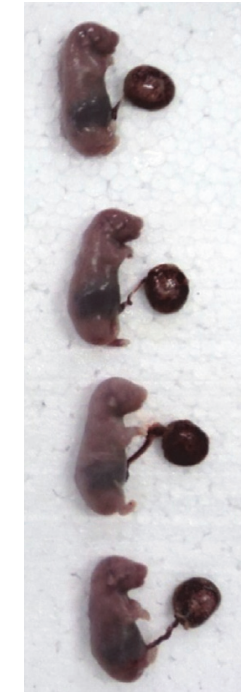

(c)

Figure 3: Fetuses obtained from experimental and control groups and treated at $25 \mathrm{mg} / \mathrm{kg}$ : (a) Control group, (b) treated group at $25 \mathrm{mg} / \mathrm{kg}$. Arrows showing embryos with interruption in the development and tiny placentas, (c) treated at $25 \mathrm{mg} / \mathrm{kg}$ presenting reduction in the number of viable fetuses.

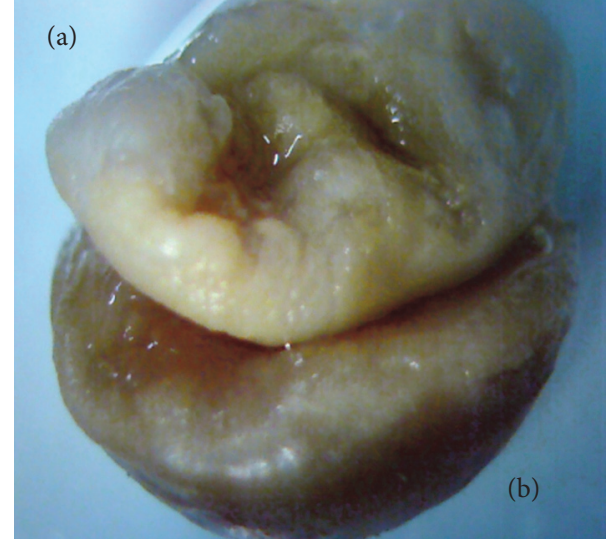

FIgURE 4: Fetus obtained from female treated with purified usnic acid at $25 \mathrm{mg} / \mathrm{kg}$ presenting interruption in embryonic development: (a) mass developing and (b) placenta.

However, it was not possible to identify a lobular organization, which is considered normal for this gestational age (20 days). The sinusoid capillaries were completely filled with blood, preventing the display of Ito cells and Kupffer cells. The structures of door spaces were not identified. Among the liver cells a large number of blood cell lineages were found at different stages of maturation. Among these, the megakaryocytes were easily identifiable.

3.4. Histomorphometric Analysis. The results from the histomorphometric analysis of the liver of pregnant rats exposed to usnic acid demonstrated significant changes in the average of the total number of hepatocytes per animal. The animals
TABLE 3: Histomorphometric analysis of the liver of pregnant rats treated with usnic acid.

\begin{tabular}{lccc}
\hline & \multicolumn{3}{c}{ Groups } \\
& G1 & G2 & G3 \\
& control $)$ & $(15 \mathrm{mg} / \mathrm{kg})$ & $(25 \mathrm{mg} / \mathrm{kg})$ \\
\hline $\mathrm{NH}$ & $90.44 \pm 15,61$ & $109.38 \pm 16,02^{*}$ & $116.96 \pm 12.67^{* * *}$ \\
$\mathrm{NCK}$ & $3.26 \pm 2.26$ & $4.03 \pm 2.62$ & $5 \pm 2.83^{* * *}$ \\
\hline
\end{tabular}

NH: number of hepatocytes; NCK: number of Kupffer cells. Data are expressed as mean \pm standard deviation. ANOVA-Tukey. ${ }^{*} P<0.05,{ }^{* * *} P<$ 0.001 compared to the control group.

exposed at $15 \mathrm{mg} / \mathrm{kg}$ showed an increase of about $21 \%$, while those exposed at $25 \mathrm{mg} / \mathrm{kg}$ had a $29 \%$ increase (Table 3).

The count of Kupffer cells for animals exposed at $15 \mathrm{mg} / \mathrm{kg}$ did not show any change in the total number of such cells per animal. The animals treated at $25 \mathrm{mg} / \mathrm{kg}$ showed an increase of about $53 \%$, when compared to the control group (Table 3 ).

The histomorphometry of fetus liver relative to the total number of hepatocytes did not show any change in the population of these cells at $15 \mathrm{mg} / \mathrm{kg}$. In contrast, at $25 \mathrm{mg} / \mathrm{kg}$ a mean increase of approximately $24 \%$ was achieved. Regarding the counting of megakaryocyte, doses of $15 \mathrm{mg} / \mathrm{kg}$ and $25 \mathrm{mg} / \mathrm{kg}$ caused a decrease of about $30 \%$ and $53 \%$, respectively (Table 4 ).

\section{Discussion}

The studies related to the toxicology of development using natural products are concentrated in the predeployment phase, in vitro culture of embryos in animal models, and in physical maturation and postnatal of the descendants. Little 


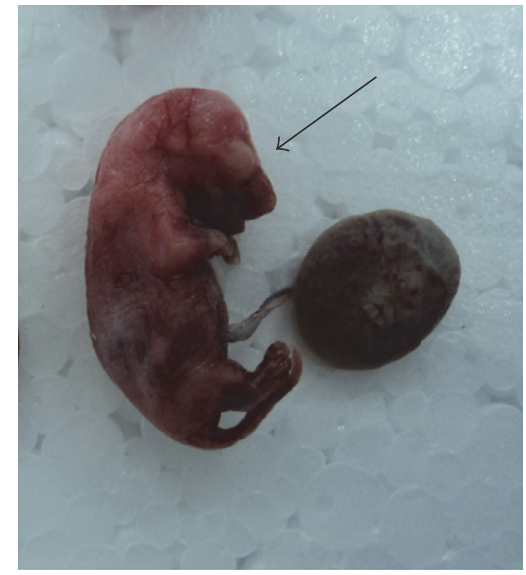

(a)

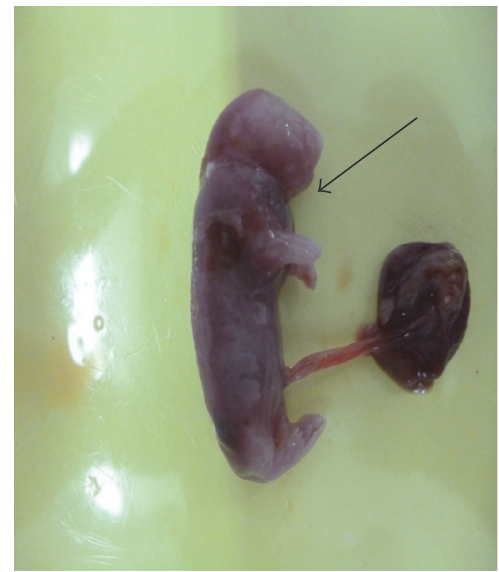

(b)

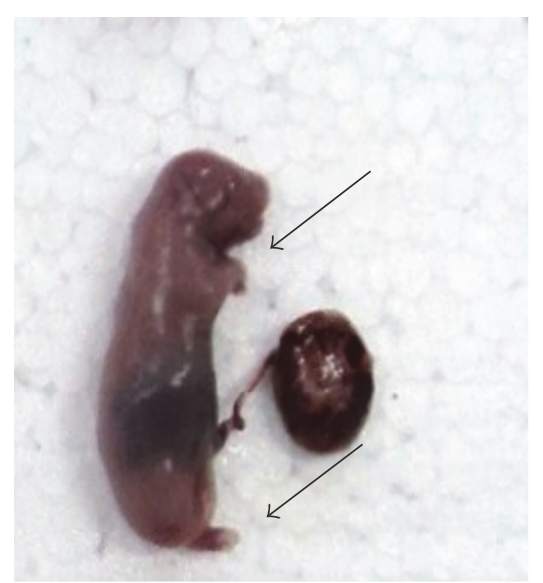

(c)

FiguRE 5: Malformations in fetuses obtained from treated females with purified usnic acid at $25 \mathrm{mg} / \mathrm{kg}$ : (a) Arrow showing protrusion of the eyeball, (b) Arrow showing cell mass in the upper region of the fetus, (c) Arrows showing atrophy of the upper and lower limbs.

TABLE 4: Histomorphometric analysis of the liver of the fetus from rats treated with usnic acid during pregnancy.

\begin{tabular}{lccc}
\hline & & Groups & \\
& G1 & G2 & G3 \\
& (control) & $(15 \mathrm{mg} / \mathrm{kg})$ & $(25 \mathrm{mg} / \mathrm{kg})$ \\
\hline $\mathrm{NH}$ & $33.4 \pm 8.6$ & $33.2 \pm 9.9$ & $41.6 \pm 6.0^{* * *}$ \\
$\mathrm{NM}$ & $0.17 \pm 0.01$ & $0.12 \pm 0.01^{*}$ & $0.08 \pm 0.01^{* * *}$ \\
\hline
\end{tabular}

$\mathrm{NH}$ : number of hepatocytes; NM: number of megakaryocytes. Data are expressed as mean \pm standard deviation. ANOVA-Tukey. ${ }^{*} P<0.05,{ }^{* * *} P<$ 0.001 compared to the control group.

is elucidated with respect to the study of toxic action during the period of organogenesis, which is considered the most important of the intrauterine stage [30-34].

The assessment of the effects of a drug on the reproductive period includes research to analyze toxicity on the maternal organism and its offspring. Signs of maternal toxicity may be related to the reduction of body weight, followed or not by a decrease in food consumption; changes in weight and/or morphology of the bodies; and the occurrence of deaths during the treatment period. Our results showed that administration of usnic acid in both doses tested interfered in maternal weight gain during pregnancy, signaling an indication of maternal toxicity of the compound [35].

Similar results can be found in reproductive toxicity studies with $\beta$-lapachone, natural compound which has some pharmacological properties similar to usnic acid. Exposure to $\beta$-lapachone at doses of $40 \mathrm{mg} / \mathrm{kg}, 60 \mathrm{mg} / \mathrm{kg}$, and $160 \mathrm{mg} / \mathrm{kg}$ for organogenesis is able to reduce body weight gain during pregnancy, induce the onset of skeletal defects in offspring, and decrease the number of fetuses per pregnancy [36].

Reduction in the number of viable fetuses per pregnancy, that is, those who continued the development after birth, is outside the normal range, because according to Krinke [37], Wistar rats of childbearing age have an average of 12 to 14 fetuses per litter.
Many of the changes observed in fetuses during intrauterine development can arise as a result of maternal exposure to teratogenic agents. This way, there is no necessarily a direct effect on progenitors. The effects of chemicals or compounds of natural origin during pregnancy can manifest as miscarriages, abnormalities, and delayed development. A very significant reduction in body weight of the conceptus is a fetotoxicity indication, inducing a delay of intrauterine development, since according to Sharp and Laregina [38], fetal body weight at birth is around $6 \mathrm{~g}$.

Interruptions in intrauterine development, when usnic acid was administered at $25 \mathrm{mg} / \mathrm{kg}$, were similar to reproductive toxicity studies of Duguetia furfuracea extracts. This product $(1 \mathrm{~mL})$, when administered orally during the preimplantation period to complete organogenesis, caused a direct effect on fetuses, delayed fetal development, presence of placenta atrophied without fetus, which clearly indicates that this was reabsorbed, and beyond external malformations, which are most obvious changes during the period of organogenesis [39].

The decrease in the weight liver of fetuses is an indication of hepatotoxic action of the usnic acid, in view of the natural and/or synthetic substances that can easily penetrate the fetal circulation through the liver before reaching the systemic circulation, and this exposure can trigger hepatotoxic effects on individuals exposed [40].

In microanatomic analyses of the liver of all animals treated with usnic acid no change was observed in hepatic tissue, such as necrotic areas. On the other hand, some studies have shown extensive lesions in the liver of animals subjected to subchronic exposure of usnic acid [4].

Histomorphometric analysis reveals a hepatotoxic effect induced by the administration of usnic acid at $25 \mathrm{mg} / \mathrm{kg}$, triggering cell proliferation of hepatocytes for a possible regeneration of liver parenchyma, a regenerative mechanism involving the increase in the number of these cells. The abnormal proliferation of liver cells can occur in various pathological and/or experimental situations, influenced by 
many factors, and in the liver an immense regenerative capacity when submitted to aggression. The regenerations of the hepatic tissue are dependent on $70 \%$ of proliferation of hepatocytes to restore normal liver architecture, in pathological conditions [41-43].

The increase in Kupffer cells in the hepatic tissue may be involved in the pathogenesis of some liver injury. According to some authors, these cells release biologically active substances, such as cytokines, which promote the pathogenic process in the tissue immediately after activation [44-46]. The morphometric study of Kupffer cells to pregnant rats exposed at $25 \mathrm{mg} / \mathrm{kg}$ is an indication of inflammation and increased liver damage due to exposure to the compound. The megakaryocytes are responsible for originating the blood platelets [43]; the reduction of multinucleated cells, megakaryocytes, in the offspring of the experimental groups confirms the toxicity of usnic acid, by changing the process of formation of these cells which can lead to a deficiency in the early stages that takes the route of blood coagulation in the body.

\section{Conclusion}

The experimental model used in this study reveals teratogenic effect of usnic acid in the period of organogenesis, and the dose of $25 \mathrm{mg} / \mathrm{kg}$ was considered the more toxic, being the dose of $15 \mathrm{mg} / \mathrm{kg}$ a candidate for new experimental research. It reveals the importance of the evaluation of the toxic effects of natural substances in order to elucidate the care in their indication as drug, particularly during pregnancy.

\section{Competing Interests}

The authors declare that there is no conflict of interests regarding the publication of this paper.

\section{Acknowledgments}

The authors are thankful to CAPES, CNPq, and FACEPE, Brazilian fostering agencies that provided scholarships. E. C. Pereira thanks CNPq for her individual grant in Research Productivity.

\section{References}

[1] K. Müller, "Pharmaceutically relevant metabolites from lichens," Applied Microbiology and Biotechnology, vol. 56, no. 12, pp. 9-16, 2001.

[2] M. Cocchietto, N. Skert, P. Nimis, and G. Sava, "A review on usnic acid, an interesting natural compound," Naturwissenschaften, vol. 89, no. 4, pp. 137-146, 2002.

[3] C. S. Vijayakumar, S. Viswanathan, M. Kannappa Reddy, S. Parvathavarthini, A. B. Kundu, and E. Sukumar, "Antiinflammatory activity of (+)-usnic acid," Fitoterapia, vol. 71, no. 5, pp. 564-566, 2000.

[4] N. P. da Silva Santos, S. C. Nascimento, M. S. O. Wanderley et al., "Nanoencapsulation of usnic acid: an attempt to improve antitumour activity and reduce hepatotoxicity," European Journal of
Pharmaceutics and Biopharmaceutics, vol. 64, no. 2, pp. 154-160, 2006.

[5] N. K. Honda, F. R. Pavan, R. G. Coelho et al., "Antimycobacterial activity of lichen substances," Phytomedicine, vol. 17, no. 5, pp. 328-332, 2010.

[6] B. C. Behera, N. Mahadik, and M. Morey, "Antioxidative and cardiovascular-protective activities of metabolite usnic acid and psoromic acid produced by lichen species Usnea complanata under submerged fermentation," Pharmaceutical Biology, vol. 50, no. 8, pp. 968-979, 2012.

[7] B. Segatore, P. Bellio, D. Setacci et al., "In vitro interaction of usnic acid in combination with antimicrobial agents against methicillin-resistant Staphylococcus aureus clinical isolates determined by FICI and $\Delta \mathrm{e}$ model methods," Phytomedicine, vol. 19, no. 3-4, pp. 341-347, 2012.

[8] D. N. Sokolov, V. V. Zarubaev, A. A. Shtro et al., "Antiviral activity of (-)- and (+)-usnic acids and their derivatives against influenza virus A(H1N1)2009," Bioorganic and Medicinal Chemistry Letters, vol. 22, no. 23, pp. 7060-7064, 2012.

[9] F. Brisdelli, M. Perilli, D. Sellitri et al., "Cytotoxic activity and antioxidant capacity of purified lichen metabolites: an in vitro study," Phytotherapy Research, vol. 27, no. 3, pp. 431-437, 2013.

[10] M. C. B. Martins, M. C. Silva, L. R. S. Silva et al., "Usnic acid potassium salt: an alternative for the control of Biomphalaria glabrata (Say, 1818)," PLoS ONE, vol. 9, no. 11, Article ID el11102, 2014.

[11] D. M. Bissell, G. J. Gores, D. L. Laskin, and J. H. Hoofnagle, "Drug-induced liver injury: mechanisms and test systems," Hepatology, vol. 33, no. 4, pp. 1009-1013, 2001.

[12] J. T. Favreau, M. L. Ryu, G. Braunstein et al., "Severe hepatotoxicity associated with the dietary supplement LipoKinetix," Annals of Internal Medicine, vol. 136, no. 8, pp. 590-595, 2002.

[13] G. W. Neff, K. Rajender Reddy, F. A. Durazo, D. Meyer, R. Marrero, and N. Kaplowitz, "Severe hepatotoxicity associated with the use of weight loss diet supplements containing ma huang or usnic acid," Journal of Hepatology, vol. 41, no. 6, pp. 1062-1064, 2004.

[14] D. Han, K. Matsumaru, D. Rettori, and N. Kaplowitz, "Usnic acid-induced necrosis of cultured mouse hepatocytes: inhibition of mitochondrial function and oxidative stress," Biochemical Pharmacology, vol. 67, no. 3, pp. 439-451, 2004.

[15] W. Sanchez, J. T. Maple, L. J. Burgart, and P. S. Kamath, "Severe hepatotoxicity associated with use of a dietary supplement containing usnic acid," Mayo Clinic Proceedings, vol. 81, no. 4, pp. 541-544, 2006.

[16] S. Chen, V. N. Dobrovolsky, F. Liu et al., "The role of autophagy in usnic acid-induced toxicity in hepatic cells," Toxicological Sciences, vol. 142, no. 1, pp. 33-44, 2014.

[17] P. Pramyothin, W. Janthasoot, N. Pongnimitprasert, S. Phrukudom, and N. Ruangrungsi, "Hepatotoxic effect of (+) usnic acid from Usnea siamensis Wainio in rats, isolated rat hepatocytes and isolated rat liver mitochondria," Journal of Ethnopharmacology, vol. 90, no. 2-3, pp. 381-387, 2004.

[18] A. Joseph, T. Lee, C. L. Moland et al., "Effect of (+)-usnic acid on mitochondrial functions as measured by mitochondriaspecific oligonucleotide microarray in liver of B6C3F1 mice," Mitochondrion, vol. 9, no. 2, pp. 149-158, 2009.

[19] S. B. M. Barros and S. C. Davino, "Avaliação da toxicidade," in Fundamentos de Toxicologia, vol. 3, pp. 59-71, Atheneu, São Paulo, Brazil, 2008. 
[20] I. P. Lemonica, S. Oga, M. M. A. Camargo, and J. A. O. Batistuzzo, Fundamentos de Toxicologia, Editora Atheneu, São Paulo, Brazil, 3rd edition, 2008.

[21] L. Schüler-Faccini, J. C. Leite, M. T. Sanseverino, and R. M. Peres, "Avaliação de teratógenos potenciais na população brasileira," Ciência \& Saúde Coletiva, vol. 7, no. 1, pp. 65-71, 2002.

[22] L. Guo, Q. Shi, J.-L. Fang et al., "Review of usnic acid and Usnea barbata toxicity," Journal of Environmental Science and Health-Part C Environmental Carcinogenesis and Ecotoxicology Reviews, vol. 26, no. 4, pp. 317-338, 2008.

[23] E. Einarsdóttir, J. Groeneweg, G. G. Björnsdóttir et al., “Cellular mechanisms of the anticancer effects of the lichen compound usnic acid," Planta Medica, vol. 76, no. 10, pp. 969-974, 2010.

[24] C. Kohlhardt-Floehr, F. Boehm, S. Troppens, J. Lademann, and T. G. Truscott, "Prooxidant and antioxidant behaviour of usnic acid from lichens under UVB-light irradiation - Studies on human cells," Journal of Photochemistry and Photobiology B: Biology, vol. 101, no. 1, pp. 97-102, 2010.

[25] B. Paudel, H. D. Bhattarai, H. K. Lee, H. Oh, H. W. Shin, and J. H. Yim, "Antibacterial activities of Ramalin, usnic acid and its three derivatives isolated from the antarctic lichen Ramalina terebrata," Zeitschrift fur Naturforschung C, vol. 65, no. 1-2, pp. 34-38, 2010.

[26] R. Lucarini, M. G. Tozatti, A. I. De Oliveira et al., "Antimycobacterial activity of Usnea steineri and its major constituent (+)usnic acid," African Journal of Biotechnology, vol. 11, pp. 46364639, 2014.

[27] Y. Asahina and S. Shibata, Chemistry of Lichen Substances, Japanese Society for the Promotion of Science, Tokyo, Japan, 1954.

[28] O. E. Virtanen and N. Karki, "On the toxicity of an usnic acid preparation with the trade name USNO," Suomen Kemistilehti, vol. 29, pp. 225-226, 1956.

[29] M. Windholz, The Merck Index: An Encyclopedia of Chemicals and Drugs, seccion 9556. Usnic Acid, Merck \& Co., Rahway, NJ, USA, 9th edition, 1976.

[30] L. Y.-S. Chan, P.-Y. Chiu, and T.-K. Lau, "A study of hypericininduced teratogenicity during organogenesis using a whole rat embryo culture model," Fertility and Sterility, vol. 76, no. 5, pp. 1073-1074, 2001.

[31] B. Gregoretti, M. Stebel, L. Candussio, E. Crivellato, F. Bartoli, and G. Decorti, "Toxicity of Hypericum perforatum (St. John's wort) administered during pregnancy and lactation in rats," Toxicology and Applied Pharmacology, vol. 200, no. 3, pp. 201205, 2004.

[32] A. C. P. Silva, D. E. P. De Faria, N. B. D. E. Santo Borges, I. A. De Souza, V. M. Peters, and M. De Oliveira Guerra, "Toxicological screening of Euphorbia tirucalli L.: developmental toxicity studies in rats," Journal of Ethnopharmacology, vol. 110, no. 1, pp. 154-159, 2007.

[33] C. B. Hollenbach, C. E. Bortolini, J. M. Batista et al., "Neonatal development and teratogenic potential of Wistar rats offspring in the study of reproductive toxicity of two commercial phytotherapic preparations with soy Glycine max (L.) Merr," Arquivo Brasileiro de Medicina Veterinaria e Zootecnia, vol. 62, no. 4 , pp. 845-852, 2010.

[34] T. de Sousa Soares, D. C. Damasceno, W. D. G. Kempinas et al., "Effect of himatanthus sucuuba in maternal reproductive outcome and fetal anomaly frequency in rats," Birth Defects Research Part B-Developmental and Reproductive Toxicology, vol. 104, no. 5, pp. 190-195, 2015.
[35] A. F. Louzada, H. Ramos, J. K. Rodrigues, and L. R. Silva, "Desenvolvimento embrionário em ratas tratadas com tacrolimus durante a fase de pré-implantação," Revista Brasileira de Ginecologia e Obstetrícia, vol. 30, pp. 219-224, 2008.

[36] E. R. De Almeida, F. R. S. Lucena, C. V. N. S. Silva et al., "Toxicological assessment of beta-lapachone on organs from pregnant and non-pregnant rats," Phytotherapy Research, vol. 23, no. 9, pp. 1276-1280, 2009.

[37] G. J. Krinke, "History, strains and models," in The Laboratory Rat, G. R. Bullock, Ed., p. 316, Academic Press, San Diego, Calif, USA, 2000.

[38] P. E. Sharp and M. C. Laregina, "Experimental methodology," in The Laboratory Rat, CRC Press, 1998.

[39] M. R. S. Toledo, M. T. L. P. Peres, M. C. Vieira, T. S. C. Bazzano, and I. R. Teixeira, "Fitoxicidade do extrato aquoso Duguetia furfuraceae (St. Hil) B em ratas (Rattus norvegicus)," Revista Brasileira de Plantas Medicinais. Botucatu, vol. 8, pp. 218-222, 2006.

[40] M. M. Bernardi, Farmacologia Aplicada à Medicina Veterinária, Editora Guanabara Koogan, 2nd edition, 2003.

[41] G. K. Michalopoulos and M. DeFrances, "Liver regeneration," Advances in Biochemical Engineering/Biotechnology, vol. 93, pp. 101-134, 2005.

[42] G. K. Michalopoulos, "Liver regeneration," Journal of Cellular Physiology, vol. 213, no. 2, pp. 286-300, 2007.

[43] K. Si-Tayeb, F. P. Lemaigre, and S. A. Duncan, "Organogenesis and development of the liver," Developmental Cell, vol. 18, no. 2, pp. 175-189, 2010.

[44] Y. Ito, N. W. Bethea, E. R. Abril, and R. S. McCuskey, "Early hepatic microvascular injury in response to acetaminophen toxicity," Microcirculation, vol. 10, no. 5, pp. 391-400, 2003.

[45] M. Ono, B. Yu, E. G. Hardison, M.-A. A. Mastrangelo, and D. J. Tweardy, "Increased susceptibility to liver injury after hemorrhagic shock in rats chronically fed ethanol: role of nuclear factor- $\kappa \mathrm{B}$, interleukin-6, and granulocyte colony-stimulating factor," Shock (Augusta, Ga.), vol. 21, no. 6, pp. 519-525, 2004.

[46] G. Kolios, V. Valatas, and E. Kouroumalis, "Role of Kupffer cells in the pathogenesis of liver disease," World Journal of Gastroenterology, vol. 12, no. 46, pp. 7413-7420, 2006. 

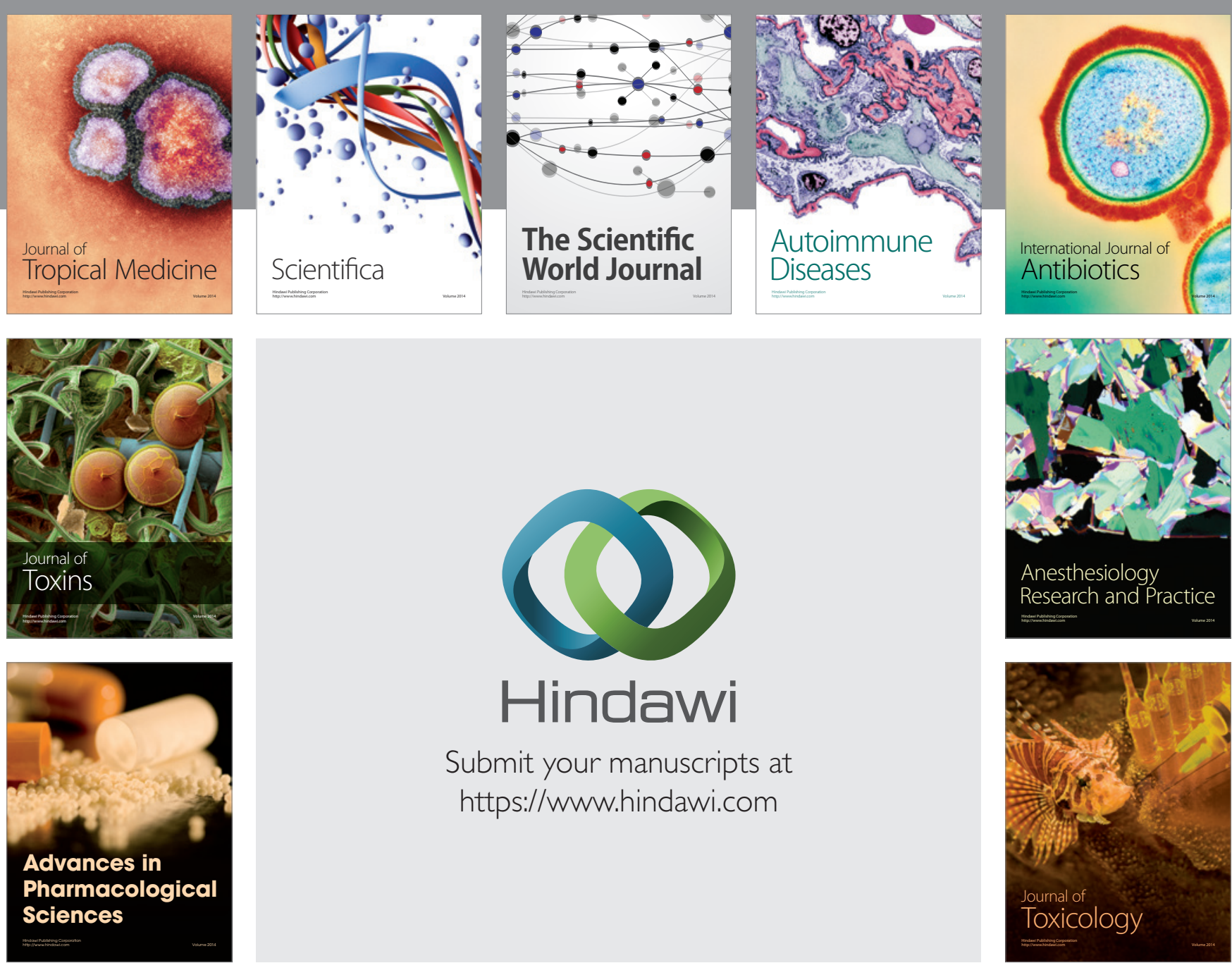

\section{Hindawi}

Submit your manuscripts at

https://www.hindawi.com
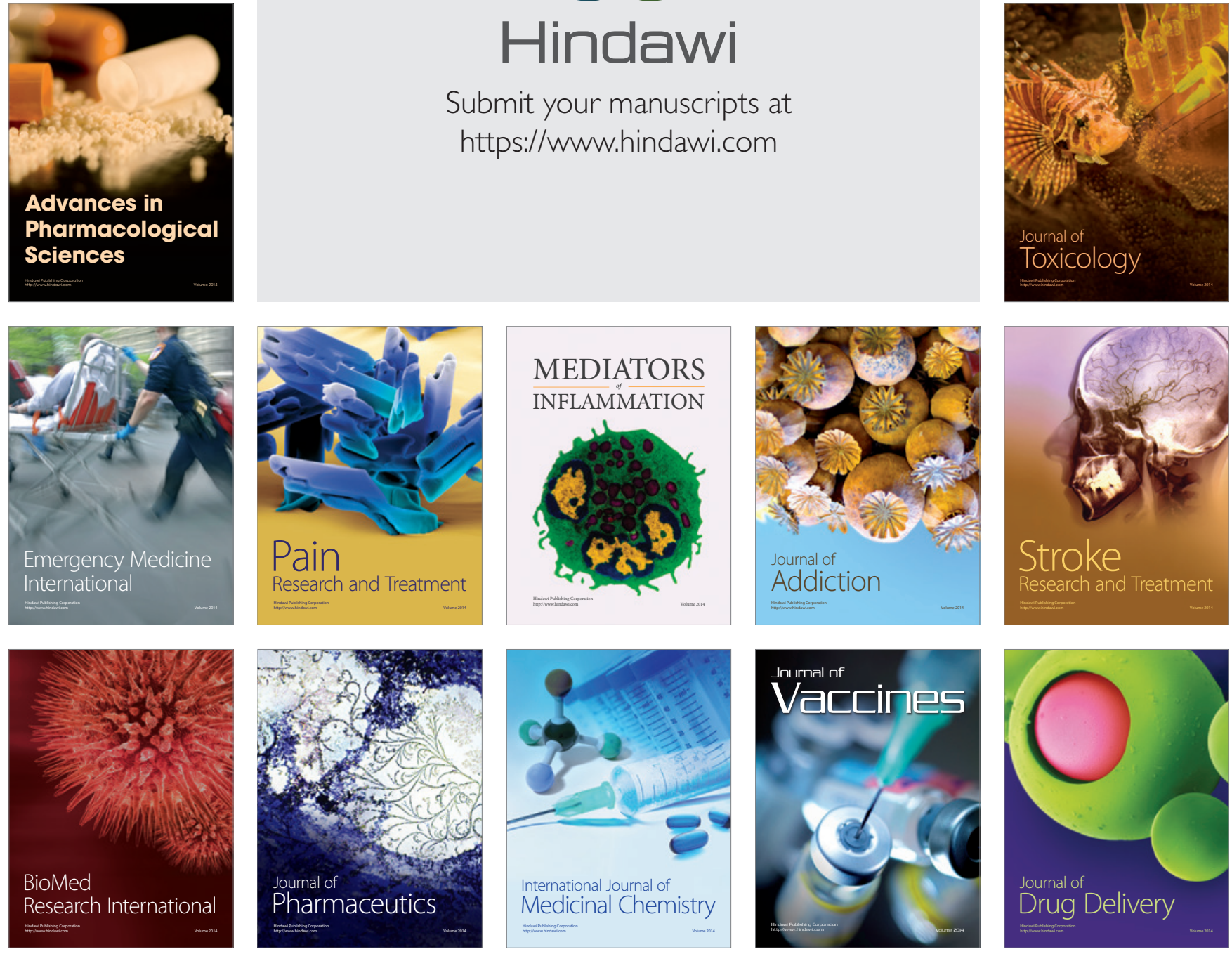